\title{
MECHANISM OF ACTION OF TUMORIGENESIS OF ANTICANCER MOLECULES OF PALM OIL TOCOTRIENOLS (Elaeis guieensis Jacq.): A SYSTEMATIC REVIEW
}

\section{Humairah Medina Liza Lubis ${ }^{1}$, Emni Purwoningsih², Annissa Ambaravista Nasution ${ }^{3}$, Qatrunnada Medina Salim 4}

Department of Anatomical Pathology, Faculty of Medicine, Universitas Muhammadiyah Sumatera Utara, Medan, Indonesia ${ }^{1}$, Department of Biochemistry, Faculty of Medicine, Universitas Muhammadiyah Sumatera Utara, Medan, Indonesia², Faculty of Medicine, Universitas Muhammadiyah Sumatera Utara, Medan, Indonesia ${ }^{3}$, Faculty of Medicine, Universitas Sumatera Utara, Medan, Indonesia 4

Email: humairahmedina@umsu.ac.id ${ }^{1}$, emnipurwoningsih@umsu.ac.id ${ }^{2}$, annissambar@yahoo.com ${ }^{3}$, nadasalim.ns@gmail.com ${ }^{4}$

\begin{tabular}{ll}
\hline ARTICLE INFO & ABSTRACT \\
\hline Received: & Palm oil contains vitamin E which comprises two \\
January, 26th & structurally similar compounds namely tocopherols and \\
2022 & tocotrienols. For many years tocopherols considered the \\
Revised: & best therapy in curing disease, but in recent research \\
February, 17th & $\begin{array}{l}\text { advances, tocotrienol has been widely used as a powerful } \\
2022\end{array}$ \\
Approved: & therapy in several diseases, including cancer. We prepared \\
February, 18 & this article to review and analyze the role of tocotrienols \\
2022 & from palm oil as anticancer molecules and their mechanism \\
& of action in the process of tumorigenesis based on the \\
& $\begin{array}{l}\text { literature from PubMed, Scopus, Science Direct, and } \\
\text { ProQuest databases published from 2011 to 2020, and }\end{array}$ \\
& according to the Preferred Reporting Items for Systematic \\
& Reviews and Meta-Analyses (PRISMA) statement. Nineteen \\
& $\begin{array}{l}\text { English articles and abstracts according to the inclusion } \\
\text { criteria, systematically reviewed and compiled. The results } \\
\text { showed that tocotrienol acts on intracellular and } \\
\text { extracellular targets involved in cell signaling pathways and }\end{array}$
\end{tabular}

Humairah Medina Liza Lubis, Emni Purwoningsih, Annissa Ambaravista Nasution, Qatrunnada Medina Salim. (2022). Mechanism of Action of Tumorigenesis of Anticancer Molecules of Palm Oil Tocotrienols (Elaeis Guieensis Jacq.): A Systematic Review.

How to cite: Journal Eduvest. Vol 2(2): 431-440

E-ISSN: 2775-3727

Published by: https://greenpublisher.id/ 


\section{Humairah Medina Liza Lubis, Emni Purwoningsih, Annissa Ambaravista Nasution,}

Qatrunnada Medina Salim

\begin{tabular}{l} 
suppresses the growth of various malignancies, including \\
breast, lung, prostate, ovarian, liver, brain, colon, \\
pancreatic, and myeloma cancers. This literature review \\
shows that the molecular mechanism of action of \\
tocotrienols has several advantages, namely a positive \\
effect on cell proliferation, apoptosis, angiogenesis, \\
metastasis, and inflammation, which when working \\
together can function as effective agents in cancer therapy. \\
The tocotrienol-mediated therapeutic action mechanism \\
could help clinicians to design new strategies for cancer \\
treatment. \\
KEYWORDS $\begin{array}{l}\text { Mechanism Of Action; Tocotrienols; Palm Oil; Therapy; } \\
\text { Cancer }\end{array}$ \\
\hline CC) (i) (O) This work is licensed under a Creative Commons \\
Attribution-ShareAlike 4.0 International
\end{tabular}

\section{INTRODUCTION}

Cancer is a deadly disease with an increasing incidence worldwide (Kashyap et al., 2017; Kashyap et al., 2018). Based on GLOBOCAN 2018 data, it is estimated that 18.1 million new cancer cases and 9.6 million deaths occurred in 2018. Conventional cancer treatment has focused on chemotherapy and radiotherapy, which sometimes have a detrimental effect on cancer patients. Therefore, the latest research is growing, especially in studying the molecular mechanism of tumorigenesis, as well as the development of new anticancer agents that are safe and effective. In recent decades, one of the main focuses of anticancer research has been on natural agents capable of fighting cancer cells (Kashyap et al., 2018).

Palm oil (Elaeis guineensis Jacq.), has been widely cultivated because the oil from the seeds and fruit is very beneficial for the industrial sector and has potential as a medicinal plant. Palm oil is also used as the main source of ingredients for kitchen needs and is widely consumed by people in Asia and Africa. More than $85 \%$ of palm oil production is provided by Indonesia and Malaysia as the main producers in the world (Mancini et al., 2015; Absalome et al., 2020).

Palm oil contains vitamin $\mathrm{E}$ which is an essential fat-soluble nutrient, obtained from food and supplements. In addition to their antioxidant activity, vitamin E components have the potential to influence various mechanisms underlying human health and disease. Vitamin E consists of two structurally similar compounds namely tocopherols and tocotrienols. The main theory states that tocotrienols have anticancer effects by inhibiting lipid peroxidation, antioxidant activity of tocotrienols can prevent oxidative damage to Deoxyribonucleic acid (DNA) and as a chemopreventive. Administration of tocotrienols in mice, rat, and human tumor cell lines has been shown to inhibit growth cancer cells (Catalgol, Batirel and Ozer, 2011; Bak et al., 2017).

Tocotrienols as a natural compound, it has been observed that it has antioxidant, antiproliferative, pro-apoptotic, anti-inflammatory, antiangiogenic, anti-invasive, and anti-metastatic activity, so it has potential as a chemopreventive or chemotherapeutic agent (Kashyap et al., 2018; Mérarchi et al., 2018; Sethi et al., 2018). In addition, the beneficial effects that have been proven are effective in lowering cholesterol levels and as 
neuroprotective, while in suppressing the growth of malignancies have been studied in the ovaries, liver, stomach, prostate, brain, blood, pancreas, and uterus (Rizvi et al., 2014; Kanchi et al., 2017).

In this literature review, we will summarize the latest data showing the unique anticancer effect, discuss the molecular mechanism of action of tumorigenesis of tocotrienols in various cancer models that can prove tocotrienols as promising chemopreventive and chemotherapeutic agents. Because in Indonesia there are so many and easy to find palm oil plants, it must be utilized as best as possible by exploring the possibility of using tocotrienols as a replacement therapy for conventional cancer treatment in Indonesia. Next we will highlight recent advances in the development and testing of tocotrienols-based cancer therapies.

\section{RESEARCH METHOD}

The study selection of relevant articles previously published from 2011 to 2020 was obtained from the PubMed, Science Direct, Scopus and ProQuest databases, using the keywords ("palm oil" OR "Elaeis guineensis Jacq.), AND ("vitamin E"), AND ("tocotrienols" OR "tocotrienols"), AND ("anti-cancer" OR "anticancer"), AND ("mechanism" OR "mechanisms"), AND ("action"), AND ("tumorigenesis"). Articles and abstracts taken are in English, read, reviewed and arranged systematically.

The studies in the selected articles met four inclusion criteria, namely: (1) sources: tocotrienols from palm oil; (2) effect: anticancer; (3) mechanism: acts on intracellular and extracellular targets involved in cell signaling pathways and has been shown to suppress the growth of various malignancies, including breast, lung, prostate, ovarian, liver, brain, colon, pancreatic, and myeloma cancers; (4) results: positive effect on cell proliferation, apoptosis, angiogenesis, metastasis, and inflammation; And articles will be excluded if: (1) palm oil content is not tocotrienols molecules; (2) has an effect on chronic diseases other than cancer (3) irrelevant results.

\section{RESULT AND DISCUSSION}

In a literature search we identified 2532 studies. Then 229 duplicate articles were removed and a further 2303 articles were carefully evaluated. Although 280 articles met the inclusion criteria, 261 were excluded because they were not eligible for this study.The number of articles analyzed was 19 articles. The study selection flowchart and reasons for rejection can be seen in Figure 1 . 


\section{Humairah Medina Liza Lubis, Emni Purwoningsih, Annissa Ambaravista Nasution, Qatrunnada Medina Salim}

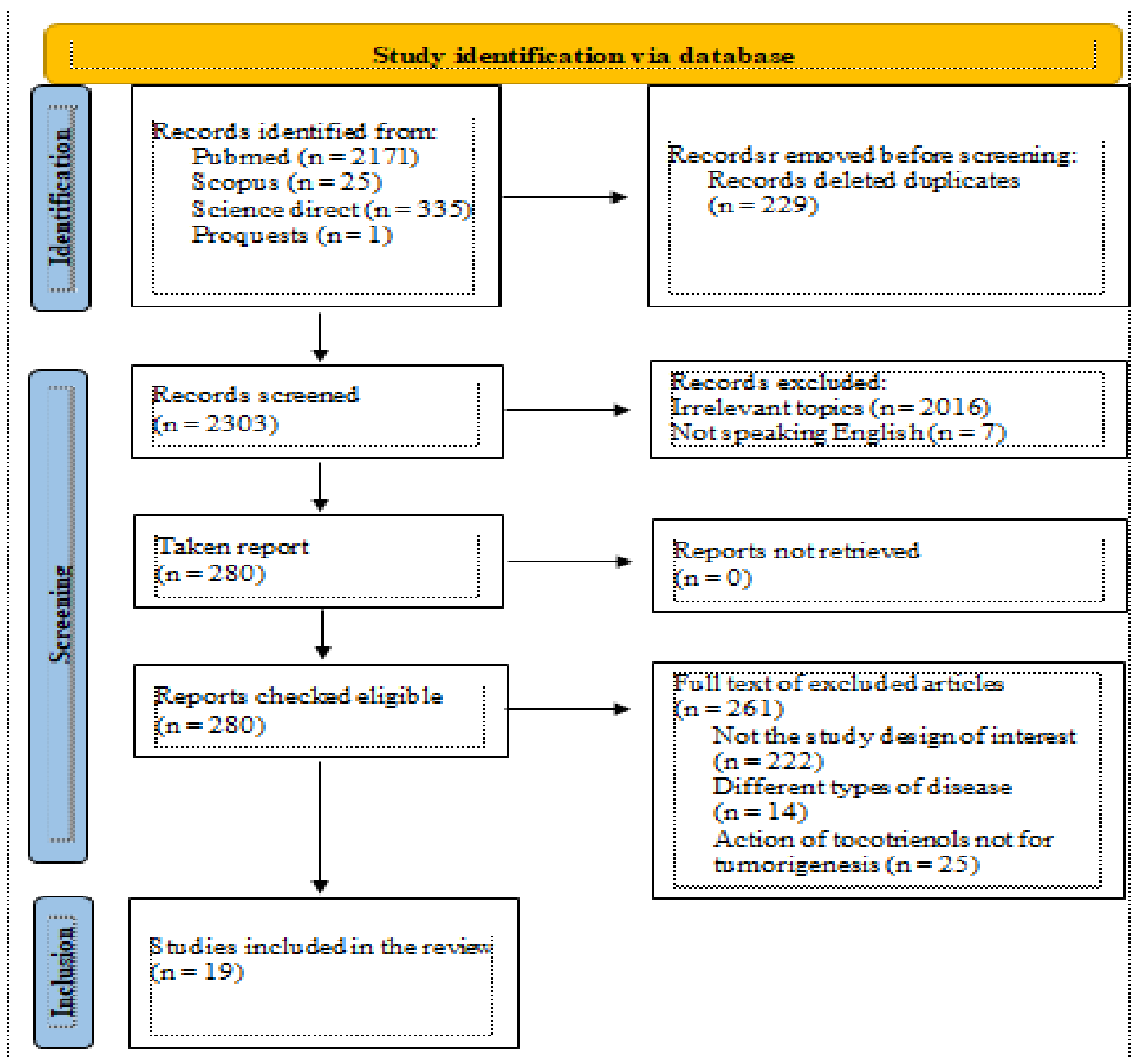

Figure 1. Study selection flowchart

\section{Main Functions of Tocotrienols as Anticancer}

Tocotrienolsis a natural form of the vitamin E group, which consists of four different isomers namely $\alpha-, \beta-, \gamma-, \delta$-tocotrienols (Peh et al., 2016). Tocotrienols are found in rice bran oil, palm oil and annatto seed (Rashid Khan et al., 2015). Tocotrienols are the main phytonutrients found in palm oil and can be found in the palm oil fraction known as the tocotrienol-rich fraction (TRF) (Subramaniam, Selvaduray and Radhakrishnan, 2019).

Various beneficial properties of tocotrienols have been reported in recent years. Tocotrienols act as cellular lipid antioxidants which are effective as anti-inflammatory, antiangiogenic, antiinvasive, and antimetastatic agents that are involved in disease cure and have potential as chemopreventive or chemotherapeutic agents although they have not been clinically tested on a large scale (Figure 2) (Mocchegiani et al., 2014; Mérarchi et al., 2018; Aggarwal et al., 2019). 


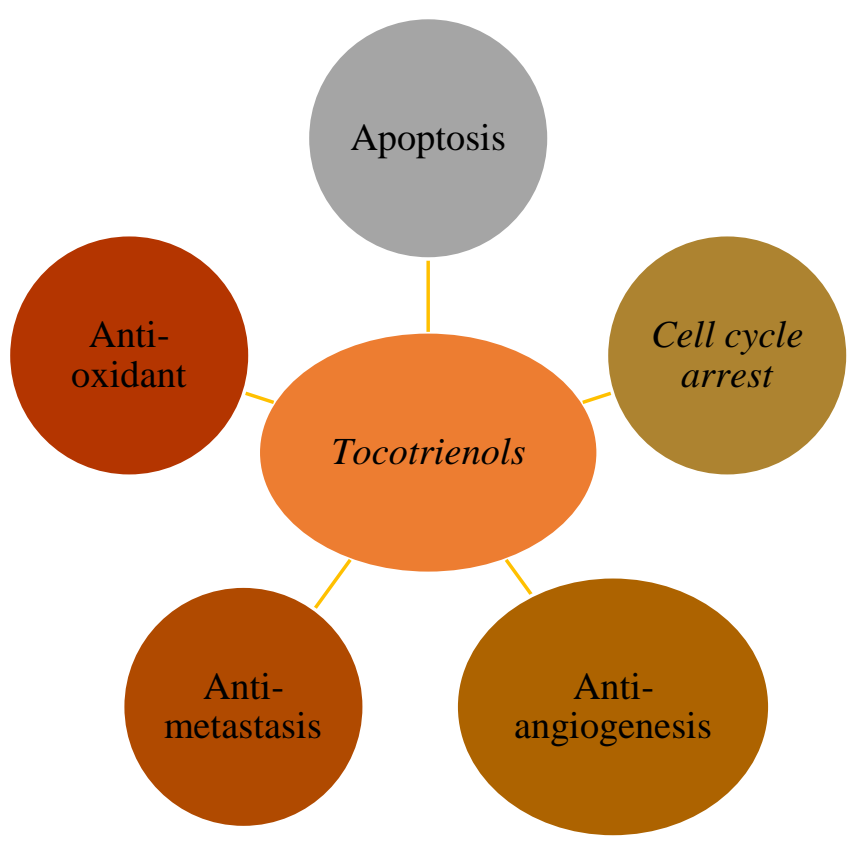

Figure 2. Anticancer properties of tocotrienols

Its chemopreventive properties have been studied extensively in a number of animal models. In contrast to the effects of tocopherols on animal models of carcinogenesis (colon, prostate, breast and lung) which often yield inconsistent results, most of the studies on tocopherols have shown positive chemopreventive effects (Ling et al., 2012).

\section{Inhibition of Cell Proliferation and Induction of Apoptosis}

Apoptosis is an important process used as an innate defense mechanism against cancer initiation (Marcus et al., 2014). Several in vitro and in vivo experiments have confirmed that apoptosis can induce the potential of natural molecules. Tocotrienols are among several natural compounds with effective antitumor activity through apoptosisinducing pathways. Tocotrienols downregulate the expression of several oncogenic gene products by inhibiting the NF-B pathway and also cause substantial apoptosis in tumor cells (Aggarwal et al., 2019).

Inhibition of proliferation and induction of apoptosis has also been reported to be mediated through tocotrienols-induced activation of the EGR-1/BAX pathway, upregulation of miR-34a125, miR-429135, p27/CDKN1B136 and PPAR- $\gamma 137$, impaired lipid formation and mitochondrial membrane modification and activation of proinflammatory genes. apoptosis. In addition, tocotrienols and their metabolite $13{ }^{`}-\mathrm{COOH}$ modulate sphingolipid metabolism through inhibition of dihydroceramide desaturase (DEGS). In addition, pathway analysis of tocotrienols-induced gene expression profiling changes showed that $-\mathrm{T} 3$ and $-\mathrm{T} 3$ alter endoplasmic reticulum stress signaling and associated autophagy and cell death (Yang et al., 2020).

\section{Tocotrienols and Cancer-related Studies}

Research about cancer using tocotrienols has been studied extensively in humans. Many studies have shown that lower tocotrienols intake or nutritional status is associated with an increased risk of various types of cancer. 


\section{Humairah Medina Liza Lubis, Emni Purwoningsih, Annissa Ambaravista Nasution, Qatrunnada Medina Salim}

Cancer, as it is widely known, is a class of diseases in which cells show uncontrolled growth and can damage surrounding tissues, and can metastasize or spread to other locations in the body via the lymph or blood vessels. Interest in the use of alternative and complementary therapies, especially tocotrienolsas a chemopreventive greatly increased especially for cancer treatment. In this study, chemoprevention by tocotrienols could slow the formation and delay the development of neoplasms. Regulation of signal transduction pathways associated with tumor formation (tumorigenesis) is considered a key point for slowing cancer progression (Catalgol, Batirel and Ozer, 2011). Figure 3 describes the mechanism of the chemopreventive effect of tocotrienols.

Increasing evidence supports the role of tocotrienols in cancer prevention. The theory about the effect of tocotrienols as anticancer is the inhibition of lipid peroxidation and with antioxidant activity it can prevent oxidative damage to DNA (Deng et al., 2019).

Research on vertebral bone metastases from prostate cancer patients using $\mathrm{VcaP}$ cell line $\mathrm{NCr}(-/-)$ nude mice of eight weeks old male injected subcutaneously with VcaPluc cells in matrigel and given a mixture of tocotrienols for 8 weeks was able to inhibit the growth of prostate tumor xenografts. man. The concentration of tocotrienols and their metabolites increased significantly in the treatment group. Tocotrienols inhibit prostate tumor growth by suppressing cell proliferation, which is associated with cyclin-dependent induction of kinase (CDK) inhibitor p21and p27 (Huang et al., 2017).

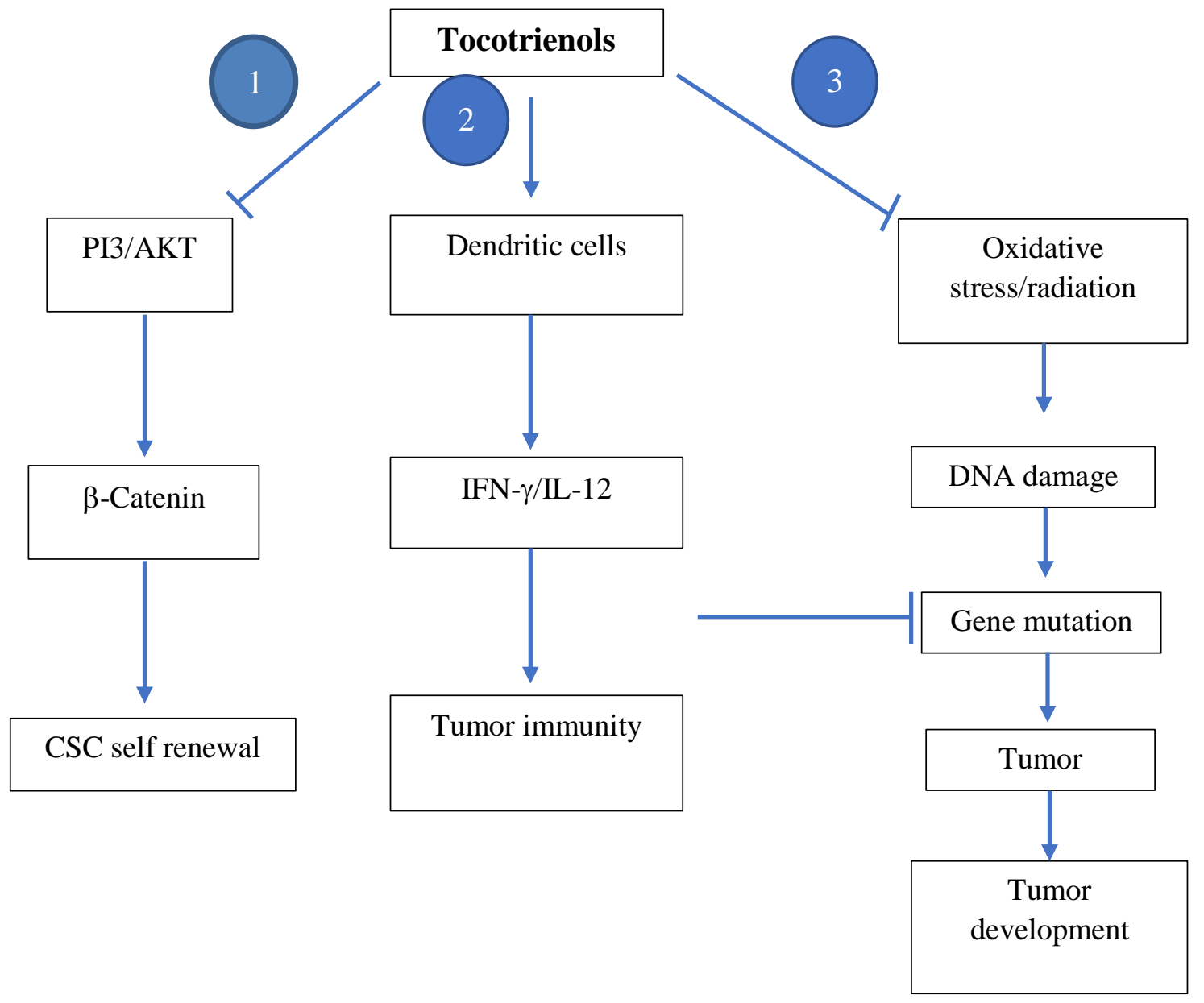


Figure 3. Chemopreventive effect of tocotrienols. Oxidative stress or radiation causes DNA damage and induces genetic mutations thereby promoting tumor development with CSCs being the tumor trigger population. The pathways occur through: 1 . Suppressing CSCs self-renewal and tumorigenicity through inactivation of the PI3/AKT/b-catenin pathway; 2. Promote dendritic cell mediated tumor immunity, tocotrienols can facilitate the elimination of tumor cells in the early stages of tumor initiation and achieve chemopreventive effects; 3 . Tocotrienols inhibit tumor development through blocking oxidative stress or radiation-induced DNA damage. Image modified from Ling et al., 2012.

In human breast cancer, several effects of tocotrienols have been shown to inhibit the growth of cancer cells. Cells were treated with $50 \mathrm{M}$ Omega 3-docosahexaenoic acid (DHA) and $5 \mathrm{M}$ vitamin E Delta-tocotrienol (Delta-T3) which showed that DHA could trigger an increase in lipid droplet (LD) biogenesis and the combination treatment with Delta-T3 was able to reduce biogenesis. LD. In addition, it was found that higher cytoplasmic LD was associated with higher malignancy and breast cancer cell proliferation (Pizato et al., 2019).

Immunotherapy research conducted Hafid and Radhakrishnan (2019) used dendritic cells with a tumor vaccine (DC vaccine) in combination with daily supplementation of TRF to enhance the antitumor immune response potency. DC vaccine immunotherapy together with TRF supplementation induces immunity to tumors. This study used female BALB/c mice induced by breast cancer (Hafid and Radhakrishnan, 2019).

Several cancer treatment and prevention studies are summarized in table 1.

Table 1. Results of clinical research on tocotrienols in various types of cancer

\begin{tabular}{|c|c|c|c|c|}
\hline Writer & $\begin{array}{c}\text { Study } \\
\text { population }\end{array}$ & Treatment & Results & Significance \\
\hline $\begin{array}{l}\text { Behery et } \\
\text { al., } 2013\end{array}$ & $\begin{array}{l}\text { Metastatic- } \\
\text { SA } \\
\text { mammary } \\
\text { epithelial } \\
\text { cancer cell } \\
\text { line }\end{array}$ & $\begin{array}{l}\delta \text {-tocotrienols } \\
\text { analogs } 10 \text { and } \\
38\end{array}$ & $\begin{array}{l}\text { Anti-proliferative } \\
\text { activity }\end{array}$ & $\begin{array}{l}\text { Tocotrienols } \\
\text { increase the } \\
\text { level and control } \\
\text { the metastatic of } \\
\text { breast } \\
\text { malignancy }\end{array}$ \\
\hline $\begin{array}{l}\text { Zhang et } \\
\text { al., } 2015\end{array}$ & $\begin{array}{l}\text { Balb/c } \\
\text { nude mice } \\
\text { inoculated } \\
\text { with } \\
\text { cancer } \\
\text { cells } \\
\text { human } \\
\text { colon } \\
\text { SW620 }\end{array}$ & $\begin{array}{l}\text { Tocotrienol-rich } \\
\text { fraction (TRF) } \\
\text { from palm oil } \\
\text { for } 6 \text { weeks }\end{array}$ & $\begin{array}{l}\text { TRF significantly } \\
\text { inhibits the growth of } \\
\text { xenografts }\end{array}$ & $\begin{array}{l}\text { The strong } \\
\text { anticancer effect } \\
\text { of TRF is } \\
\text { associated } \\
\text { with Wnt . signal } \\
\text { pathway } \\
\text { regulation }\end{array}$ \\
\hline $\begin{array}{l}\text { Springett et } \\
\text { al., } 2015\end{array}$ & $\begin{array}{l}\text { Pancreatic } \\
\text { cancer }\end{array}$ & $\begin{array}{l}\text { Vitamin E - } \\
\text { tocotrienols } \\
\text { (VEDT) at a } \\
\text { dose of 200- } \\
\text { 3200mg per day }\end{array}$ & $\begin{array}{l}\text { Biological activity, in } \\
\text { the form of apoptotic } \\
\text { induction, was seen to } \\
\text { be significant in } \\
\text { neoplastic cells as }\end{array}$ & $\begin{array}{l}\text { The results are } \\
\text { significant but } \\
\text { require further } \\
\text { clinical research } \\
\text { from VEDT to }\end{array}$ \\
\hline
\end{tabular}




\section{Humairah Medina Liza Lubis, Emni Purwoningsih, Annissa Ambaravista Nasution, Qatrunnada Medina Salim}

\begin{tabular}{|c|c|c|c|c|}
\hline & & $\begin{array}{l}\text { for } 13 \text { days } \\
\text { before surgery } \\
\text { and a single } \\
\text { dose on the day } \\
\text { of surgery }\end{array}$ & $\begin{array}{l}\text { measured by elevated } \\
\text { levels of caspase- } 3\end{array}$ & $\begin{array}{l}\text { chemopreventio } \\
\mathrm{n} \text { and/or } \\
\text { pancreatic } \\
\text { cancer therapy }\end{array}$ \\
\hline $\begin{array}{l}\text { Shanmuga } \\
\text { m et al., } \\
2017\end{array}$ & $\begin{array}{l}\text { Preclinical } \\
\text { several } \\
\text { types of } \\
\text { cancer }\end{array}$ & Tocotrienol & $\begin{array}{l}\text { Several growth factors } \\
\text { and their receptors } \\
\text { such as } \\
\text { VEGF/VEGFR, } \\
\text { bFGF/FGFR, } \\
\text { angiopoietin, and } \\
\text { hypoxia-induced } \\
\text { factors facilitate the } \\
\text { development of } \\
\text { angiogenesis and are } \\
\text { anti-cancer targets }\end{array}$ & $\begin{array}{l}\text { Tocotrienols } \\
\text { exhibit } \\
\text { prominent anti- } \\
\text { angiogenic } \\
\text { effects in a } \\
\text { preclinical } \\
\text { model of tumor } \\
\text { angiogenesis }\end{array}$ \\
\hline $\begin{array}{l}\text { Fontana et } \\
\text { al., } 2019\end{array}$ & $\begin{array}{l}\text { Castration- } \\
\text { resistant } \\
\text { prostate } \\
\text { cancer } \\
\text { (CRPC) }\end{array}$ & $\begin{array}{l}\text { Vitamin E- } \\
\text { derived } \\
\text { tocotrienols } \square \mathrm{T} \\
\text { T on selmCRPC } \\
\text { (PC3 and } \\
\text { DU145) }\end{array}$ & $\begin{array}{l}\delta \text {-TT provides } \\
\text { cytotoxic/proapoptotic } \\
\text { activity in } \\
\text { CRPC cells }\end{array}$ & $\begin{array}{l}\text { Apoptosis } \\
\text { involves ER } \\
\text { stress and } \\
\text { autophagy } \\
\text { (in autophagy- } \\
\text { positive PC3 } \\
\text { cells), and } \\
\text { paraptosis is } \\
\text { involved in anti- } \\
\text { cancer activity } \\
\delta \text {-TT in CRPC } \\
\text { cells. }\end{array}$ \\
\hline
\end{tabular}

\section{CONCLUSION}

A wide variety of bioactive compounds isolated from natural products including tocotrienols, have various therapeutic benefits and potential for cancer prevention and treatment. The mechanism of action of tocotrienols at the cellular and molecular levels leads to the modulation of various cancer-associated signaling pathways. The tocotrienols-mediated therapeutic action mechanism could help researchers and clinicians to design new strategies for cancer treatment.

\section{REFERENCES}

Absalome, MA et al. (2020). Biochemical properties, nutritional values, health benefits and sustainability of palm oil, Biochimie, 178, pp. 81-95. doi: 10.1016/j.biochi.2020.09.019.

Aggarwal, V. et al. (2019). Molecular mechanisms of action of tocotrienols in cancer: Recent trends and advancements, International Journal of 
Molecular Sciences, 20(3). doi:10.3390/ijms20030656.

Bak, MJ et al. (2017). Inhibitory effects of G- and d-tocopherols on estrogenstimulated breast cancer in vitro and in vivo, Cancer Prevention Research, 10(3), pp. 188-197. doi: 10.1158/1940-6207.CAPR-16-0223.

Behery, FA et al. (2013). Optimization of tocotrienols as antiproliferative and antimigratory leads, European Journal of Medicinal Chemistry, 59, pp. 329-341. doi:10.1016/j.ejmech.2012.11.012.

Bray, F. et al. (2018). Global cancer statistics 2018: GLOBOCAN estimates of incidence and mortality worldwide for 36 cancers in 185 countries, CA: A Cancer Journal for Clinicians, 68(6), pp. 394-424. doi: 10.3322/caac.21492.

Catalgol, B., Batirel, S. and Ozer, NK (2011). Cellular Protection and Therapeutic Potential of Tocotrienols, Current Pharmaceutical Design, 17(21), pp. 2215-2220. doi: 10.2174/138161211796957436.

Deng, S. et al. (2019). Targeting autophagy using natural compounds for cancer prevention and therapy, Cancer, 125(8), pp. 1228-1246. doi:10.1002/cncr.31978.

Fontana, F. et al. (2019). Tocotrienol induces apoptosis, involving endoplasmic.pdf, Cell Proliferation, 52(e12576), pp. 1-15. doi: https://doi.org/10.1111/cpr.12576.

Hafid, SRA and Radhakrishnan, AK (2019). Palm tocotrienol-adjuvanted dendritic cells decrease expression of the SATB1 gene in murine breast cancer cells and tissues, Vaccines, 7(4). doi:10.3390/vaccines7040198.

Huang, Y. et al. (2017). A naturally occurring mixture of tocotrienols inhibits the growth of human prostate tumor, associated with epigenetic modifications of cyclin-dependent kinase inhibitors p21 and p27, Journal of Nutritional Biochemistry, 40, pp. 155-163. doi: 10.1016/j.jnutbio.2016.10.019.

Kanchi, MM et al. (2017). Tocotrienols: the unsaturated sidekick shifting new paradigms in vitamin E therapeutics, Drug Discovery Today, 22(12), pp. 1765-1781. doi: 10.1016/j.drudis.2017.08.001.

Kashyap, D. et al. (2017). Kaempferol - A dietary anticancer molecule with multiple mechanisms of action: Recent trends and advancements', Journal of Functional Foods, 30, pp. 203-219. doi: 10.1016/j.jff.2017.01.022.

Kashyap, D., Sharma, A., Deaf, HS, et al. (2018). Apigenin: A natural bioactive flavone-type molecule with promising therapeutic function', Journal of Functional Foods, 48(July), pp. 457-471. doi: 10.1016/j.jff.2018.07.037.

Kashyap, D., Sharma, A., Sak, K., et al. (2018). Fisetin: A bioactive phytochemical with potential for cancer prevention and pharmacotherapy, Life Sciences, 194(February), pp. 75-87. doi: 10.1016/j.lfs.2017.12.005.

Kashyap, D., Deaf, H., et al. (2018). Ursolic acid and quercetin: Promising anticancer phytochemicals with antitimetastatic and antiangiogenic potential, Tumor and Microenvironment, 1(1), p. 9. doi: 10.4103/tme.tme_3_17.

Ling, MT et al. (2012). Tocotrienols as a potential anticancer agent, Carcinogenesis, 33(2), pp. 233-239. doi:10.1093/carcin/bgr261. 
Mancini, A. et al. (2015). Biological and nutritional properties of palm oil and palmitic acid: Effects on health, Molecules, 20(9), pp. 17339-17361. doi: 10.3390/molecules200917339.

Marcus, A. et al. (2014). Recognition of tumors by the innate immune system and natural killer cells, Advances in immunology, 122, pp. 91-128. doi: https://doi.org/10.1016/B978-0-12-800267-4.00003-1.

Méarchi, M. et al. (2018). Molecular targets modulated by fangchinoline in tumor cells and preclinical models, Molecules, 23(10), pp. 1-13. doi: 10.3390/molecules23102538.

Mocchegiani, E. et al. (2014). Vitamin E-gene interactions in aging and inflammatory age-related diseases: Implications for treatment. A systematic review, Aging Research Reviews, 14(1), pp. 81-101. doi:10.1016/j.arr.2014.01.001.

Peh, HY et al. (2016). Vitamin E therapy beyond cancer: Tocopherol versus tocotrienol, Pharmacology and Therapeutics, 162, pp. 152-169. doi:10.1016/j.pharmthera.2015.12.003.

Pizato, N. et al. (2019). Omega 3-DHA and delta-tocotrienol modulate lipid droplet biogenesis and lipophagy in breast cancer cells: The impact in cancer aggressiveness, Nutrients, 11(6), pp. 1-18. doi: 10.3390/nu11061199.

Rashid Khan, M. et al. (2015). Tocotrienols have a nephroprotective action against lipid-induced chronic renal dysfunction in rat', Renal Failure, 37(1), pp. 136-143. doi: 10.3109/0886022X.2014.959433.

Rizvi, S. et al. (2014) 'ات يف لا لـ ماو ر شد بلان',14(May), pp. 157-165.

Sethi, G. et al. (2018). Pro-apoptotic and anti-cancer properties of diosgenin: A comprehensive and critical review', Nutrients, 10(5). doi:10.3390/nu10050645.

Shanmugam MK, Warrier S, Kumar AP, Sethi G, AF (2017). Potential Role of Natural Compounds as Anti-Angiogenic Agents in Cancer, Curr Vasc Pharmacol, $15(6), \quad$ pp. $503-519 . \quad$ doi: 10.2174/1570161115666170713094319.

Springett, GM et al. (2015). A Phase I Safety, Pharmacokinetic, and Pharmacodynamic Presurgical Trial of Vitamin E -tocotrienol in Patients with Pancreatic Ductal Neoplasia, EBioMedicine, 2(12), pp. 1987-1995. doi:10.1016/j.ebiom.2015.11.025.

Subramaniam, S., Selvaduray, KR and Radhakrishnan, AK (2019). Bioactive compounds: Natural defense against cancer, Biomolecules, 9(12). doi: 10.3390/biom9120758.

Yang, CS et al. 2020. Vitamin E and cancer prevention: Studies with different forms of tocopherols and tocotrienols, Molecular Carcinogenesis, 59(4), pp. 365-389. doi:10.1002/mc.23160.

Zhang, JS et al. (2015). Tocotrienol-Rich Fraction (TRF) suppresses the growth of human colon cancer xenografts in Balb/C nude mice by the Wnt pathway', PLoS ONE, 10(3), pp. 1-15. doi: 10.1371/journal.pone.0122175. 